ISSN: 2302-8556

E-Jurnal Akuntansi Universitas Udayana

Vol.24.3.September (2018): 1658-1686

DOI: https://doi.org/10.24843/EJA.2018.v24.i03.p01

\title{
Pengaruh Struktur Audit, Komitmen Organisasi, dan Gaya Kepemimpinan Transformasional Pada Kinerja Auditor
}

\section{Gusti Ngurah Agung Dicky Wibawa ${ }^{1}$ Ida Bagus Putra Astika ${ }^{2}$}

\author{
${ }^{1}$ FakultasEkonomidanBisnisUniversitasUdayana, Bali, Indonesia \\ email:agungdicky26@gmail.com/Telp : 082144949713 \\ ${ }^{2}$ FakultasEkonomidanBisnisUniversitasUdayana, Bali, Indonesia
}

\begin{abstract}
ABSTRAK
Populasi dalam penelitian ini adalah seluruh auditor kantor akuntan publik di Bali yang tergabung dalam Institut Akuntan Publik Indonesia. Metode pengambilan sampel yang digunakan adalah metode puposive sampling, sedangkan data dikumpulkan melalui teknik kuesioner. Teknik analisis data yang digunakan adalah teknik analisis kuantitatif yang meliputi analisis regresi linier berganda. Target responden penelitian ini adalah 70 responden, namun data responden yang dapat diolah adalah 53 jawaban responden. Hasil penelitian ini menunjukkan bahwa variabel struktur audit, komitmen organisasi, dan gaya kepemimpinan transformasional berpengaruh positif dan signifikan pada kinerja auditor. Hal ini bermakna bahwa penggunaan struktur audit dapat membantu auditor dalam melaksanakan tugasnya menjadi lebih baik, begitu pula tingkat komitmen yang tinggi pada organisasinya maka kinerja akan semakin baik, dan memiliki gaya kepemimpinan transformasional dapat memberikan nuansa pada kinerja auditor.

Kata Kunci: Struktur audit, komitmen organisasi, gaya kepemimpinan transformasional, kinerja auditor.
\end{abstract}

\begin{abstract}
Population in this research is all auditor of public accountant office in Bali which incorporated in Indonesian Institute of Certified Public Accountant. Sampling method used is puposive sampling method, while data collected through questionnaire technique. Data analysis techniques used are quantitative analysis techniques that include multiple linear regression analysis. Target respondents of this research is 70 respondents, but the respondent data that can be processed is 53 respondents' answers. The results of this study indicate that the audit structure variable, organizational commitment, and transformational leadership style have positive and significant influence on auditor performance. This means that the use of the audit structure can help the auditor perform better in his duties, as well as the high level of commitment to his organization, the better performance, and the transformational leadership style can give a sense of the auditor's performance.

Keywords: Audit structure, organizational commitment, transformational leadership style, auditor performance.
\end{abstract}




\section{PENDAHULUAN}

Kinerja suatu Kantor Akuntan Publik yang berkualitas sangat ditentukan oleh kinerja para akuntannya. Profesi akuntan publik merupakan profesi kepercayaan masyarakat. Profesi akuntan memiliki peran yang sangat penting dalam penyediaan informasi keuangan yang handal bagi pemerintah, kreditor, investor, debitur, pemegang saham, karyawan, juga bagi masyarakat dan pihak-pihak lain yang berkepentingan (Boyton \& Kell, 2006: 16 dalam Suseno, 2013). Dengan kata lain profesi akuntan sangat penting bagi para stakeholder dari suatu perusahaan.Dari profesi akuntan publik, yang diharapkan oleh masyarakat yaitu penilaian yang bebas dan tidak memihak terhadap informasi dalam laporan keuangan yang disajikan oleh manajemen perusahaan (Mulyadi, 2009:4). Warren dan Alzola (2008) menyatakansecara umum auditor memiliki tanggung jawab bertindak secara objektif. Meningkatkan keandalan laporan keuangan perusahaan merupakan tanggung jawab profesi akuntan publik, maka informasi keuangan yang andal sebagai dasar pengambilan keputusan dapat diperoleh oleh masyarakat. Maka dari itu, auditor dituntut untuk memaksimalkan kinerja pada klien dan para pemakai laporan keuangan auditan lainnya. Menurut Rahmawati (2011), profesi akuntan memiliki peran yang sangat penting bagi masyarakat yang berhubungan dengan tugas dan tanggung jawab auditor.

Seorang auditor dalam proses audit memberikan opini kewajaran dengan judgment yang didasarkan pada kejadian masa lalu, sekarang, maupun masa yang akan datang (Jamilah dkk, 2007). Seorang auditor dituntut untuk mampu menyajikan informasi yang memiliki relevansi, reabilitas, daya uji, netralitas, dan 
disajikan dengan tepat. Keberadaan auditor juga tidak terlepas dari adanya kebutuhan manajemen mengenai pertanggungjawaban dan transparansi atas kinerja perusahaan. Auditor dituntut untuk dapat memediasi berbagai perbedaan kepentingan yang dimiliki oleh para pelaku bisnis dan masyarakat. Agar dapat menjalankan perannya, auditor selalu menjaga mutu dan kualitas jasa yang diberikannya kepada kliennya. Seorang auditor dituntut untuk memiliki profesionalisme yang tinggi dalam menjalankan tugas-tugasnya dan dapat mempertanggungjawabkan hasil auditnya kepada pihak-pihak yang berkepentingan dan baik buruknya pertanggungjawaban yang diberikan tergantung dari kinerja auditor.

Kinerja auditor adalah kemampuan dari seorang auditor dalam menghasilkan temuan atau hasil dari kegiatan pemeriksaan atas pengelolaan dan tanggung jawab keuangan yang dilakukan dalam satu tim (Yanhari, 2007 dalam Satwika, 2015). Kinerja auditor merupakan suatu tindakan ataupun pelaksanaan tugas pemeriksaan yang telah diselesaikan oleh auditor dalam kurun waktu tertentu. Goldwasser (1993) dalam Hanif (2013) menyatakan bahwa pencapaian kinerja auditor yang lebih baik harus sesuai dengan standar dan kurun waktu tertentu, yaitu : mutu menyelesaikan pekerjaan dengan bekerja berdasarkan pada seluruh kemampuan dan keterampilan serta pengetahuan yang dimiliki oleh auditor, hasil kerja yang dapat diselesaikan dengan target yang menjadi tanggung jawab pekerjaan auditor serta kemampuan untuk memanfaatkan sarana dan prasarana penunjang pekerjaan dan yang terakhir ketepatan waktu yang tersedia untuk menyelesaikan pekerjaan. 
Kinerja auditor merupakan hasil kerja yang dicapai oleh auditor dalam melaksanakan tugasnya sesuai dengan tanggung jawab yang diberikan padanya dan menjadi salah satu tolak ukur yang digunakan untuk menentukan apakah suatu pekerjaan yang dilakukan akan baik atau sebaliknya. Oleh karena itu,yangmenjadi perhatian utama bagi klien atau publik dalam menilai hasil audit adalah kinerja auditor. Salah satu hal yang berpengaruh pada kinerja auditor dan dapat mempengaruhi kepercayaan masyarakat terhadap akuntan publik sebagai pihak yang independen dalam pengauditan laporan keuangan yaitu kondisi kerja yang kurang kondusif.

Kinerja auditor tergantung interaksi antara kompleksitas tugas dengan struktur audit yang digunakan dalam penerimaan audit. Untuk tugas analitis yang tidak terlalu kompleks, auditor dari perusahaan yang menggunakan struktur audit dan tidak menggunakan struktur audit menunjukkan kinerja yang sepadan. Sebaliknya, pada tugas yang relatif kompleks, auditor dari perusahaan yang tidak menggunakan struktur audit jauh berada di bawah perusahaan yang menggunakan struktur audit. Selanjutnya penelitian yang dilakukan Fananiet al. (2007) mengenai pengaruh struktur audit pada kinerja auditor, hasilnya struktur audit mempunyai pengaruh positif atau signifikan pada kinerja auditor. Hal ini berarti penggunaan struktur audit dapat membantu auditor dalam melaksanakan tugasnya menjadi lebih baik, sehingga dapat meningkatkan kinerja auditor.

Struktur Audit adalah sebuah pendekatan sistematis terhadap audit yang dikarakteristikkan oleh langkah-langkah penentuan audit, prosedur rangkaian logis, keputusan, dokumentasi, dan menggunakan sekumpulan alat-alat dan 
kebijakan audit, yang komprehensif dan terintegrasi untuk membantu auditor melakukan audit (Bowrin, 1998 dalam Fanani, Hanif, dan Subroto, 2008).Hal ini berkaitan dengan koordinasi arus kerja, wewenang yang dimiliki, komunikasi dan kemampuan beradaptasi sehingga pengguna pendekatan struktur audit diharapkan dapat meningkatkan kinerja auditor menjadi lebih baik (Bamber et al. 1989).Pendekatan struktur audit memiliki beberapa keuntungan yaitu dapat mengurangi litigasi yang dihadapi KAP, dapat mendorong efisiensi, dapat mendorong efektivitas, mempunyai dampak positif terhadap konsekuensi sumber daya manusia dan dapat memfasilitasi diferensiasi pelayanan atau kualitas sehingga diduga dapat meningkatkan kinerja auditor.

Komitmen organisasi merupakan sikap yang merefleksikan loyalitas karyawan pada organisasi dan berkelanjutan sehingga anggota organisasi dapat mengekspresikan perhatiannya terhadap organisasi dan keberhasilan serta kemajuan yang berkelanjutan (Luthans, 2006;249). Setiap organisasi memiliki keinginan untuk mencapai kinerja yang optimal, yang sangat dipengaruhi oleh komitmen yang dimiliki karyawan yang ada didalam organisasi tersebut. Anggota yang memiliki komitmen terhadap organisasinya maka dia akan lebih bertahan sebagai bagian dari organisasi dibandingkan anggota yang tidak memiliki komitmen terhadap organisasi, dengan kata lain ketika seseorang menyukai organisasi tempat dia bekerja maka dia akan memberikan kemampuan yang terbaik dan loyal untuk organisasinya tersebut.

Auditor yang memiliki komitmen terhadap organisasi akan menunjukkan sikap dan gaya kepemimpinan yang baik terhadap tempat ia bekerja, auditor akan 
memiliki rasa yang besar untuk membela organisasinya, berusaha meningkatkan prestasinya serta memiliki keyakinan yang pasti dalam hal mewujudkan tujuan organisasi (Arifah, 2012).Hasil studi Ketchan dan Strawser (2001) dalam Marganingsih dan Martini, yang menguji berbagai dimensi dari komitmen organisasi menunjukan adanya hubungan antara komitmen organisasi dengan kinerja. Studi Siders et al (2001), dan Fernando et al (2005) dalam Marganingsih dan Martini, memberikan simpulan yang sama bahwa komitmen organisasi berpengaruh positif terhadap kinerja.

Penelitian tersebut mendukung penelitian sebelumnya yang membuktikan bahwa komitmen organisasi mempunyai hubungan positif dan signifikan dengan kinerja individu (Mayer dan Scoorman, 1992 dalam Marganingsih dan Martini). Namun penemuan tersebut mendapat tanggapan kontra dari Somers dan Bimbaum (1998) dalam Wibowo (2009) yang menyatakan bahwa komitmen organisasional (affective dan continuance) tidak berhubungan dengan kinerja.

Gaya kepemimpinan transformasional merupakan gaya kepemimpinan yang menginspirasi pengikut untuk terlibat, berkomitmen, dan memiliki visi serta tujuan bagi organisasi mereka, mendorong pengikut menjadi inovatif didalam memecahkan masalah organisasi, dan mendukung pengikut untuk memiliki kompetensi dalam kepemimpinan melalui pembinaan dan pengawasan (Indrayanto et al. 2013).Kepemimpinan transformasional adalah pemimpin yang menginspirasi para pengikut untuk melampaui kepentingan pribadi mereka dan yang mampu membawa dampak mendalam dan luar biasa pada pengikutnya (Cavazott et al. 2011). Seseorang yang menjalankan fungsi manajemen 
berkewajiban mempengaruhi karyawan yang dibawahinya agar mereka tetap melaksanakan tugas dengan baik, memilki dedikasi terhadap organisasi, dan tetap merasa berkewajiban untuk mencapai tujuan organisasi.

Hasil penelitian sebelumnya mengenai pengaruh struktur audit terhadap kinerja auditor yang dilakukan Stuart (2004) hasilnya menunjukan bahwa struktur audit tidak berpengaruh secara langsung pada kinerja auditor. Kinerja auditor tergantung interaksi antara kompleksitas tugas dengan struktur audit yang digunakan dalam penerimaan audit. Untuk tugas analitis yang tidak terlalu kompleks, auditor dari perusahaan yang menggunakan struktur audit dan tidak menggunakan struktur audit menunjukkan kinerja yang sepadan. Sebaliknya, pada tugas yang relatif kompleks, auditor dari perusahaan yang tidak menggunakan struktur audit jauh berada di bawah perusahaan yang menggunakan struktur audit.

Penelitian yang dilakukan Fananiet al. (2007) mengenai pengaruh struktur audit pada kinerja auditor, hasilnya struktur audit mempunyai pengaruh positif atau signifikan pada kinerja auditor. Hal ini berarti penggunaan struktur audit dapat membantu auditor dalam melaksanakan tugasnya menjadi lebih baik, sehingga dapat meningkatkan kinerja auditor.Hasil penelitian yang dilakukan oleh Tintamin, dkk, (2012) mengemukakan bahwa gaya kepemimpinan transformasional meningkatkan kinerja auditor. Sina (2013) juga menyatakan bahwa ada pengaruh positif antara gaya kepemimpinan transformasional dengan kinerja auditor. Temuan ini memberikan indikasi bahwa gaya kepemimpinan transformasional sangat berpengaruh terhadap kinerja auditor. Di samping itu, untuk mendapatkan kinerja yang baik diperlukan juga adanya pemberian 
pembelajaran pada bawahannya. Demikian pula gaya kepemimpinan sangat diperlukan karena dapat memberikan nuansa pada kinerja auditor.

Berdasarkan uraian diatas maka pokok permasalahan dalam penelitian ini sebagai berikut:1) Apakah struktur audit berpengaruh pada kinerja auditor di KAP wilayah Bali?; 2) Apakah komitmen organisasi berpengaruh pada kinerja auditor di KAP wilayah Bali ?; 3) Apakah gaya kepemimpinan transformasional berpengaruh pada kinerja auditor di KAP wilayah Bali ?.Adapun tujuan yang ingin dicapai dalam penelitian ini sebagai berikut: 1)Untuk mendapatkan bukti empiris pengaruh struktur audit pada kinerja auditor; 2) Untuk mendapatkan bukti empiris pengaruh komitmen organisasi pada kinerja auditor; 3) Untuk mendapatkan bukti empiris pengaruh gaya kepemimpinan transformasional pada kinerja auditor.

Triandis (1971) mengembangkan Theory of attitude and Behaviour yang dipandang sebagai teori yang dapat mendasari untuk menjelaskan indepedensi. Teori tersebut menyatakan , bahwa perilaku ditentukan untuk apa orang-orang ingin lakukan (sikap), apa yang mereka pikirkan akan mereka lakukan (aturanaturan sosial), apa yang mereka bisa lakukan (kebiasaan), dan dengan konsekuensi perilaku yang mereka pikirkan. Sikap terdiri dari komponen kognitif yaitu keyakinan, komponen afektif yaitu suka atau tidak suka, berkaitan dengan apa yang dirasakan dan komponen perilaku yaitu bagaimana seorang ingin berperilaku terhadap sikap.

Sikap adalah keadaan dalam diri manusia yang menggerakan untuk bertindak, menyertai manusia dengan perasaan-perasaan tertentu dalam 
menanggapi objek yang terbentuk atas dasar pengalaman-pengalaman. Seseorang membentuk sikap dari pengalaman pribadi, orang tua, panutan masyarakat, dan kelompok sosial. Ketika pertama sekali seseorang mempelajarinya sikap menjadi suatu bentuk bagian dari pribadi individu yang membantu konsistensi perilaku. Para akuntan publik harus memahami sikap dalam rangka memahami dan memprediksikan perilaku.

Mangkunegara (2005:67) mengemukakan bahwa istilah kinerja berasal dari kata actual performance atau job performance (prestasi yang sesungguhnya dicapai seseorang atau prestasi kerja), yaitu hasil kerja secara kuantitas dan kualitas yang dicapai oleh seorang pegawai dalam melaksanakan tugasnya sesuai dengan tanggungjawab yang diberikan kepadanya. Gambaran mengenai tingkat pencapaian pelaksanaan suatu kegiatan/program/kebijakan dalam mewujudkan sasaran, tujuan, misi dan visi organisasi yang tertuang dalam strategic planning suatu organisasi merupakan pengertian dari kinerja (performance). Prestasi atau tingkat keberhasilan individu maupun kelompok sering disebut dengan istilah kinerja.

(Gibson et al. 1996) dalam Marganingsih dan Martini, menyatakan bahwa kinerja karyawan merupakan suatu ukuran yang dapat digunakan untuk menetapkan perbandingan hasil pelaksanaan tugas, tanggung jawab yang diberikan oleh organisasi pada periode tertentu dan relatif dapat digunakan untuk mengukur prestasi kerja atau kinerja organisasi. Beberapa peneliti terdahulu percaya bahwa karyawan yang dapat mengontrol dan mengelola stres dengan baik 
ketika bekerja, kinerja karyawan tersebut di perusahaan akan lebih tinggi (Ciarrochi et al. 2002).

Menurut Mahsun dkk, (2007) istilah kinerja sering digunakan untuk menyebut prestasi atau tingkat keberhasilan seorang individu maupun kelompok individu. Pengertian kinerja auditor menurut Ristio dkk, (2014) dalam Heny (2015) adalah kinerja auditor merupakan hasil dari kerja auditor dalam melaksanakan tugasnya sesuai dengan tanggung jawab auditor tersebut. Mulyadi dan Kanaka (1998:116) menyatakan bahwa pengertian kinerja auditor adalah auditor yang melaksanakan penugasan pemeriksaan (examination) secara objektif atas laporan keuangan suatu entitas (perusahaan atau organisasi lain) dengan tujuan untuk menentukan apakah laporan keuangan tersebut disajikan secara wajar sesuai dengan prinsip akuntansi yang berlaku umum, dalam semua hal yang material, posisi keuangan dan hasil usaha perusahaan.

Kinerja auditor merupakan tindakan atau pelaksanaan tugas pemeriksaan yangtelah diselesaikan oleh auditor dalam kurun waktu tertentu. Kalbers dan Forgarty (1995) dalam Wibowo (2009) mengemukakan bahwa kinerja auditor sebagai evaluasi terhadap pekerjaan yang dilakukan oleh atasan, rekan kerja, diri sendiri, dan bawahan langsung. Bedasarkan pengertian diatas dapat disimpulkan bahwa kinerja (prestasi kerja) auditor adalah hasil karya yang dicapai seorang auditor dalam melaksanakan tugas-tugas yang diberikan kepadanya yang didasarkan atas kecakapan, pengalaman, dan kesungguhan waktu yang diukur dengan mempertimbangkan kuantitas, kualitas dan ketepatan waktu. 
Kinerja (prestasi kerja) dapat diukur melalui pengukuran tertentu (standar), dimana kualitas adalah berkaitan dengan mutu kerja yang dihasilkan, kuantitas adalah jumlah hasil kerja yang diahsilkan dalam kurun waktu tertentu, ketepatan waktu adalah kesesuaian waktu yang telah direncanakan, indepedensi berarti sikap mental seorang auditor yang tidak memihak, tidak dipengaruhi, tidak bergantung pada pihak lain, serta jujur, objektif dalam mengungkapkan fakta dan menyatakan opinin, profesionalisme yaitu perilaku yang menandai profesi seorang auditor yang selalu memperhitungkan baik dan buruk serta risiko dalam menjalankan pekerjaannya, dan indepedensi.

Pengertian struktur audit menurut Bowrin (1998) dalam Fanani, Hanif, dan Subroto (2008), yaitu sebuah pendekatan sistematis terhadap auditing yang dikarakteristikkan oleh langkah-langkah penentuan audit, prosedur rangkaian logis, keputusan, dokumentasi, dan menggunakan sekumpulan alat-alat dan kebijakan audit yang komprehensif dan terintegrasi untuk membantu auditor melakukan audit. Hal ini berkaitan dengan koordinasi arus kerja, wewenang yang dimiliki, komunikasi dan kemampuan beradaptasi sehingga pengguna pendekatan struktur audit diharapkan dapat meningkatkan kinerja auditor menjadi lebih baik (Bamber et al. 1989).Peneliti yang telah mengkaji struktur audit terhadap kinerja auditor diantaranya adalah Bamber et al. (1989). Hasil penelitian sebelumnya mengenai pengaruh struktur audit terhadap kinerja auditor yang dilakukan Stuart (2004) hasilnya menunjukan bahwa struktur audit tidak berpengaruh secara langsung pada kinerja auditor. 
Kalbers dan Fogarty (1995) dalam Wibowo (2009) menggunakan dua pandangan tentang komitmen organisasional yaitu, affective dan continuance. Hasil dari penelitiannya mengungkapkan bahwa komitmen organisasi Affective berhubungan dengan satu pandangan profesionalisme yaitu pengabdian pada profesi, yang merupakan keterikatan emosional terhadap organisasi dimana pegawai mengidentifikasikan diri dengan organisasi dan menikmati keanggotaan dalam organisasi, sedangkan komitmen organisasi continuance berhubungan secara positif dengan pengalaman dan secara negatif dengan pandangan profesionalisme kewajiban sosial.

Menurut Meyer dan Allen dalam Luthans (2006), komitmen organisasi bersifat multidimensi, maka terdapat perkembangan untuk dukungan tiga model, yaitu: komitmen afektif yang berhubungan dengan keterikatan emosional karyawan, identifikasi, dan keterlibatan dalam organisasi; komitmen kelanjutan yang berdasarkan kerugian yang berhubungan dengan keluarnya karyawan dengan organisasi; dan komitmen normatif yaitu perasaan wajib untuk tetap berada dalam organisasi, tindakan tindakan tersebut merupakan hal benar yang harus dilakukan. Sedangkan Buchanan dan Vadenberg (1992) dalam Wibowo (2009) mendefinisikan komitmen sebagai penerimaan karyawan atas nilai-nilai organisasi (indentification), keterlibatan secara psikologis (psychological immersion), dan loyalitas (affection attachement).

Gaya kepemimpinan transformasional merupakan gaya kepemimpinan yang menginspirasi pengikut untuk terlibat, berkomitmen, dan memiliki visi serta tujuan bagi organisasi mereka, mendorong pengikut menjadi inovatif didalam 
memecahkan masalah organisasi, dan mendukung pengikut untuk memiliki kompetensi dalam kepemimpinan melalui pembinaan dan pengawasan (Indrayanto et al. 2013). Kepemimpinan transformasional adalah pemimpin yang menginspirasi para pengikut untuk melampaui kepentingan pribadi mereka dan yang mampu membawa dampak mendalam dan luar biasa pada pengikutnya (Cavazott et al. 2011). Gaya kepemimpinan merupakan salah satu faktor penting yang dapat mempengaruhi kinerja bawahan.

Hasil penelitian yang dilakukan oleh Tintamin, dkk, (2012) mengemukakan bahwa gaya kepemimpinan transformasional meningkatkan kinerja auditor. Menurut Adeyemi and Fagbemi (2010) kepemimpinan berdampak positif pada kinerja auditor. Sina (2013) juga menyatakan bahwa ada pengaruh positif antara gaya kepemimpinan transformasional dengan kinerja auditor.

Desain penelitian menunjukan pengaruh antar variabel dalam penelitian ini. Berdasarkan latar belakang dan kajian teoritis diatas maka dapat digambarkan desain penelitian dalam penelitian ini yang disajikan pada Gambar 1 seperti berikut:

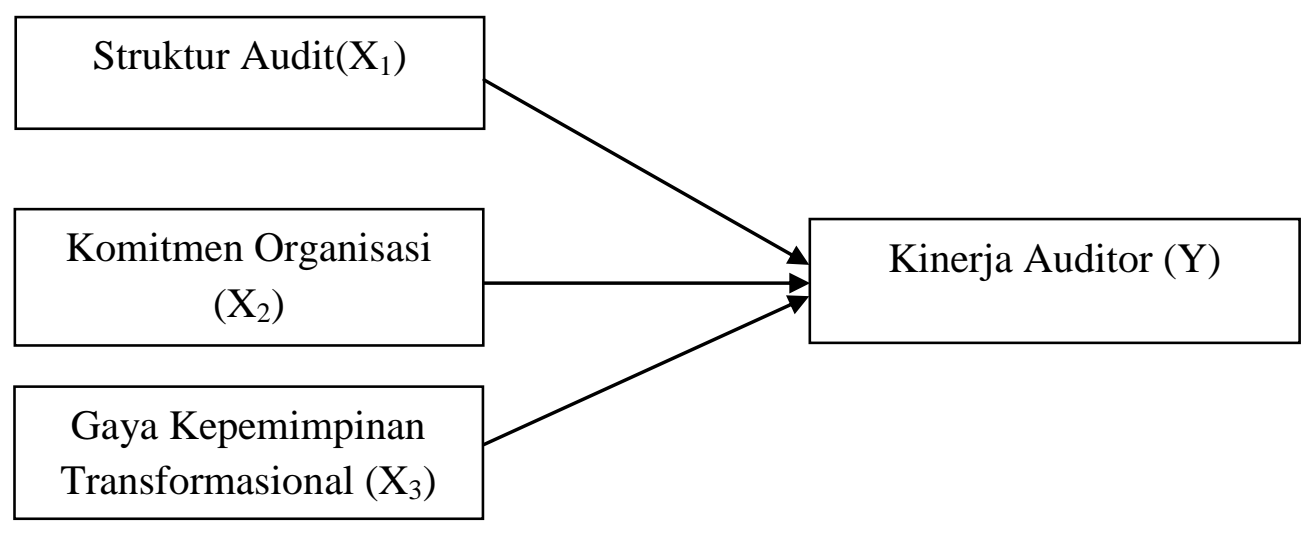

Gambar 1. Desain Penelitian 
Staf audit yang tidak memiliki pengetahuan tentang struktur audit baku cenderung mengalami kesulitan dalam menjalani tugasnya. Hal ini berkaitan dengan koordinasi arus kerja, wewenang yang dimiliki, komunikasi, dan kemampuan beradaptasi. Hasil penelitian sebelumnya mengenai pengaruh struktur audit pada kinerja auditor yang dilakukan Stuart (2004) hasilnya menunjukkan bahwa struktur audit tidak berpengaruh secara langsung pada kinerja auditor. Penelitian yang dilakukan Fanani et al. (2007) dan Ramadhan (2017) mengenai pengaruh struktur audit pada kinerja auditor, hasilnya struktur audit mempunyai pengaruh positif atau signifikan pada kinerja auditor. Penelitian Bamber et al didukung oleh Fanani, Hanif, dan Subroto (2008) yang juga menyatakan bahwa dengan digunakannya struktur audit akan membantu auditor dalam melaksanakan tugasnya dengan lebih baik. Berdasarkan penjelasan tersebut maka dapat dirumuskan hipotesis sebagai berikut:

$\mathrm{H}_{1}$ : Struktur audit berpengaruh positif pada kinerja auditor.

Meyer et al. (1989) dalam Wibowo (2009) menguji hubungan antara kinerja manajer tingkat atas dengan komitmen affective berkorelasi secara positif dengan kinerja, sedangkan komitmen continuance berkorelasi secara negatif dengan kinerja. Temuan tersebut didukung oleh Trisnaningsih (2007) dalam Wibowo (2009) yang menyatakan bahwa komitmen organisasi berpengaruh positif signifikan terhadap kinerja. Namun, temuan tersebut berlawanan dengan Somers dan Bimbaum (1989) dalam Wibowo (2009) mengemukakan bahwa komitmen organisasional (affective dan continuance) tidak berpengaruh terhadap kinerja. Komitmen dapat menjadi dorongan bagi seseorang untuk bekerja lebih 
baik atau malah sebaliknya menyebabkan seseorang justru meninggalkan pekerjaanya, akibat suatu tuntutan komitmen lainnya. Komitmen yang tepat akan memberikan motivasi yang tinggi dan memberikan dampak yang positif terhadap kinerja suatu pekerjaan. Berdasarkan uraian diatas dan penelitian sebelumnya, dapat dirumuskan hipotesis penelitian sebagai berikut :

$\mathrm{H}_{2}$ : Komitmen organisasi berpengaruh positif pada kinerja auditor.

Kepemimpinan transformasional yaitu pemimpin yang mencurahkan perhatiannya kepada persoalan-persoalan yang dihadapi oleh para pengikutnya dengan cara memberikan semangat dan dorongan untuk mencapai tujuannya.Timothy (2011) mengungkapkan bahwa dengan model kepemimpinan transformasional maka bawahan merasa percaya, merasa kagum, setia dan hormat terhadap pemimpin untuk lebih banyak memberikan dorongan. Gaya kepemimpinan transformasional dapat mempengaruhi kreativitas kinerja auditor dalam melaksanakan tugasnya sebagai anggota organisasi. Pemimpin mendorong bawahan untuk lebih sadar akan kepentingan tugas dan membujuk untuk mendapatkan hasil yang lebih untuk kepentingan organisasi atau tim. Berdasarkan uraian diatas, maka dapat dirumuskan hipotesis penelitian sebagai berikut :

$\mathrm{H}_{3}$ : Gaya Kepemimpinan Transformasional berpengaruh positif pada kinerja auditor.

\section{METODE PENELITIAN}

Penelitian ini di lakukan pada Kantor Akuntan Publik yang berada diProvinsi Bali dan merupakan anggota Institusi Akuntan Publik Indonesia (IAPI). Pendekatan 
yang digunakan dalam penelitian ini adalah pendekatan kuantitatif yang berbentuk asosiatif. Penelitian ini menguji pengaruh variabel struktur audit, komitmen organisasi, dan gaya kepemimpinan transformasional pada kinerja auditor.

Populasi dalam penelitian ini adalah seluruh auditor yang bekerja pada Kantor Akuntan Publik di Provinsi Bali, yang merupakan anggota IAPI tahun 2017 sebanyak 80 auditor. Sampel penelitian ini adalah individu yaitu auditor yang bekerja pada 9 Kantor Akuntan Publik di Provinsi Bali yaitu 80 auditor. Teknik penentuan sampel yang digunakan dalam penelitian ini adalahmetodenonprobability dengan teknik purposive samplingyaitu auditor yang bekerja pada kantor akuntan publik di Bali yang terdaftar pada Institut Akuntan Publik Indonesia (IAPI) tahun 2017.Metode pengumpulan data dalam penelitian ini adalah metode survei dengan teknik kuisioner yaitu metode yang digunakan untuk memperoleh data primer yang relevan dengan objek penelitian berupa serangkaian pertanyaan atau pernyataan tertulis kepada responden untuk dijawabnya (Sugiyono, 2014:199). Dalam penelitian ini, kuesioner langsung diantarkan ke lokasi penelitian dan diberikan kepada respondenyang diukur dengan menggunakan skala likert 1-5.

Jenis dan sumberdata yang digunakan dalam sebuah penelitian, yaitu jenis data kualitatif dan kuantitaif. Data kualitatif adalah data yang berbentuk kata, kalimat, skema dan gambar (Sugiyono, 2014:14). Data kualitatif dalam penelitian ini berupa daftar nama kantor akuntan publik yang tergabung dalam Institut Akuntan Publik Indonesia wilayah Bali. Data kuantitatif yaitu data yang berbentuk angka atau data kualitatif yang diangkakan. Data kuantitaif dalam 
penelitian ini adalah jumlah auditor yang bekerja pada masing-masing KAP dan hasil kuesioner yang berupa jawaban responden yang diukur dengan skala Likert.

Berdasarkan sumbernya data dibagi menjadi dua (Sugiyono, 2014:193) yaitu Data Primer yaitu sumber data yang langsung memberikan data kepada pengumpul data. Data yang dimaksud adalah jawaban-jawaban yang diberikan oleh responden atas pertanyaan-pertanyaan dalam kuesioner yang berhubungan dengan penelitian.Data sekunder sumber yang tidak langsung memberikan data kepada pengumpul data, misalnya lewat orang lain atau dokumen. Data sekunder dalam penelitian ini berupa daftar nama kantor akuntan publik di Bali yang tergabung dalam Institut Akuntan Publik Indonesia dan jumlah auditor yang bekerja pada masing-masing KAP tersebut.

Definisi operasional variabel Independen pada penelitian ini adalah: 1) Struktur Audit (X1), menurut Bowrin (1998) dalam Fanani, Hanif, Dan Subroto (2008), struktur audit yaitu sebuah pendekatan sistematis terhadap audit yang dikarakteristikkan oleh langkah-langkah penentuan audit, prosedur rangkaian logis, keputusan, dokumentasi, dan menggunakan sekumpulan alat-alat dan kebijakan audit yang komprehensif dan terintegrasi untuk membantu auditor melakukan audit. Indikator variabel ini diukur dengan 5 pertanyaan yang diadopsi dari kuesioner Yunilma (2000) dalam Fanani, Hanif, dan Subroto (2008). 2)Komitmen Organisasi (X2), komitmen organisasi didefinisikan sebagai kekuatan yang bersifat relatif dari individu dalam organisasi. Hal ini merefleksikan sikap individu akan tetap sebagai anggota organisasi yang ditunjukkan dengan kerja kerasnya. Indikator variabel komitmen organisasi ini 
diukur dengan menggunakan instrument yang dikembangkan oleh Meyer dan Allen (1984), dan telah direplikasikan oleh Trisnaningsih (2003) dalam Wibowo (2009). Komitmen Organisasi diukur dengan 12 dimensi. 3) Gaya Kepemimpinan Transformal (X3), gaya kepemimpinan transformasional merupakan gaya kepemimpinan yang menginspirasi pengikut untuk terlibat, berkomitmen, dan memiliki visi serta tujuan bagi organisasi mereka, mendorong pengikut menjadi inovatif didalam memecahkan masalah organisasi, dan mendukung pengikut untuk memiliki kompetensi dalam kepemimpinan melalui pembinaan dan pengawasan (Indrayanto et al. 2013). Indikator gaya kepemimpinan transformasional menggunakan instrumen yang dikembangkan oleh Gibson (1996) dalam Wibowo (2009). Gaya kepemimpinan transformasional diukur dengan 9 pertanyaan.

Definisi operasional variabel dependen pada penelitian ini adalah kinerja auditor (Y), kinerja (prestasi kerja) auditor adalah suatu hasil karya yang dicapai oleh seorang auditor dalam melaksanakan tugas-tugas yang dibebankan kepadanya yang didasarkan atas kecakapan, pengalaman, dan kesungguhan waktu yang diukur dengan mempertimbangkan kuantitas, kualitas, dan ketepatan waktu. Indikator kinerja auditor diukur dengan 12 instrumen yang dikembangkan oleh Mautz dan Sharaf (1961) dan Wibowo (2009).

Teknik analisis data yang digunakan dalam penelitian ini adalah teknik analisis linier berganda. Analisis tersebut dapat dihitung dengan menggunakan alat bantu komputer yaitu programStatistic Package for the Social Science(SPSS). Bentuk umum dari persamaan linier berganda secara sistematis sebagai berikut: 
$Y=\alpha+\beta_{1} \cdot X_{1}+\beta_{2} \cdot X_{2}+\beta_{3} \cdot X_{3}+\varepsilon$

Keterangan:

$\mathrm{Y}=$ Kinerja Auditor

$\alpha=$ Konstan

$\mathrm{X}_{1}=$ Struktur audit

$\mathrm{X}_{2}=$ Komitmen organisasi

$\mathrm{X}_{3}=$ Gaya kepemimpinan transformasional

$\beta_{1}=$ Koefisien regresi struktur audit

$\beta_{2}=$ Koefisien regresi komitmen organisasi

$\beta_{3}=$ Koefisien regresi gaya kepemimpinan transformasional

$\varepsilon=$ Error

\section{HASIL DAN PEMBAHASAN}

Statistik deskriptif disajikan untuk memberikan informasi mengenai karakteristik variabel-variabel penelitian yang terdiri dari jumlah amatan, nilai minimum, nilai rata-rata, dan standar deviasi (simpangan baku) dengan $\mathrm{N}$ merupakan banyaknya responden penelitian. Hasil analisis statistik deskriptif dapat dilihat dalam Tabel 1. berikut,

Tabel 1.

Hasil Statistik Deskriptif

\begin{tabular}{lccccc}
\hline Variabel & N & Minimum & Maximum & Mean & Std. Deviation \\
\hline Struktur Audit & 53 & 5,00 & 19,61 & 14,0945 & 4,52366 \\
Komitmen Organisasi & 53 & 12,00 & 42,98 & 32,1855 & 11,16614 \\
Gaya Kepemimpinan & 53 & 10,78 & 33,06 & 24,4864 & 8,22337 \\
Transformasional & 53 & 6,00 & 22,44 & 16,4525 & 5,57554 \\
Kinerja Auditor & & &
\end{tabular}

Sumber: Data diolah, 2017

Tabel 1. menunjukkan bahwa variabel struktur audit $\left(\mathrm{X}_{1}\right)$ memiliki nilai rata-rata sebesar 14,0945 dengan nilai minimum 5,00 dan nilai maksimum 19,61. Hal ini menunjukkan penggunaan struktur audit dalam melaksanakan tugas audit pada kinerja auditor sudah dapat dilaksanakan, karena dapat dilihat nilai rata-rata lebih mendekati nilai maksimal, yang artinya sebagian besar responden cenderung 
menjawab rinci pada 5 item pernyataan dalam variabel struktur audit. Lebih lanjut dapat dilihat bahwa rata-rata per item struktur audit 2,81 yang diperoleh dari angka rata-rata 14,0945 dibagi 5 item pernyataan. Hal ini bermakna bahwa struktur audit masih perlu dilihat tahapan atau rinciannya sehingga mencapai struktur audit yang ideal yang implikasinya berdampak pada kinerja auditor yang semakin baik.

Variabel komitmen organisasi $\left(\mathrm{X}_{2}\right)$ memiliki nilai rata-rata sebesar 32,1855 dengan nilai minimum 12,00 dan nilai maksimum 42,98. Hal ini menunjukkan komitmen organisasi yang diterapkan dalam kinerja auditor pada Kantor Akuntan Publik (KAP) sudah dapat dilaksanakan. Hal tersebut juga dapat dilihat dari nilai rata-rata lebih mendekati nilai maksimal, yang artinya sebagian besar responden cenderung menjawab setuju pada 5 item pernyataan dalam variabel komitmen organisasi. Lebih lanjut dapat dilihat bahwa rata-rata per item komitmen organisasi 2,68 yang diperoleh dari angka rata-rata 32,1855 dibagi 12 item pernyataan. Hal ini bermakna bahwa komitmen organisasi diantaranya rasa memiliki, keterikatan, loyalitas, komitmen, profesional akan semakin meningkat sehingga kinerja auditor pun akan semakin baik.

Variabel gaya kepemimpinan transformasional $\left(\mathrm{X}_{3}\right)$ memiliki nilai ratarata sebesar 24,4864 dengan nilai minimum 10,78 dan nilai maksimum33,06. Hal ini menunjukkan gaya kepemimpinan transformasional yang diterapkan dalam diri seorang auditor sudah dapat dilaksanakan. Hal tersebut juga dapat dilihat dari nilai 
rata-rata lebih mendekati nilai maksimal, yang artinya sebagian besar responden cenderung menjawab setuju pada 5 item pernyataan dalam variabel gaya kepemimpinan transformasional. Lebih lanjut dapat dilihat bahwa rata-rata per item komitmen organisasi 2,72 yang diperoleh dari angka rata-rata 24,4864 dibagi 9 item pernyataan. Hal ini bermakna bahwa gaya kepemimpinan transformasional diantaranya rasa kepercayaan, komunikasi, arahan dari pimpinan, akan semakin meningkat sehingga kinerja auditor pun akan semakin baik.

Variabel kinerja auditor (Y) memiliki nilai rata-rata sebesar 16,4525 dengan nilai minimum 6,00 dan nilai maksimum 22,44. Hal ini menunjukkan kinerja auditor dalam melaksanakan tugas auditnya sudah dilaksanakan. Hal tersebut juga dapat dilihat dari nilai rata-rata lebih mendekati nilai maksimal, yang artinya sebagian besar responden cenderung menjawab setuju pada 5 item pernyataan dalam variabel kinerja auditor. Lebih lanjut dapat dilihat bahwa ratarata per item komitmen organisasi 2,74 yang diperoleh dari angka rata-rata 16,4525 dibagi 6 item pernyataan. Hal ini bermakna bahwa kinerja auditor diantaranya tingkat pendidikan, pengalaman, loyalitas, motivasi, akan semakin meningkat sehingga kinerja auditor pun akan semakin baik.

Analisis regresi linier berganda digunakan untuk mengukur pengaruhvariabel bebas terhadap variabel terikat. Dalam model analisis pada penelitian ini, yang digunakan sebagai variabelbebas adalah adalah struktur audit $\left(\mathrm{X}_{1}\right)$ komitmen organisasi $\left(\mathrm{X}_{2}\right)$, dan gaya kepemimpinan transformasional $\left(\mathrm{X}_{3}\right)$. Sedangkan yang digunakan sebagai variabel terikat pada penelitian ini adalah 
kinerja auditor (Y). Berikut adalah hasil analisis regresi linier bergandayang disajikan pada Tabel 2 .

Tabel 2.

\section{Hasil Uji Regresi Linier Berganda}

\begin{tabular}{|c|c|c|c|c|c|}
\hline \multirow[t]{2}{*}{ Model } & \multicolumn{2}{|c|}{$\begin{array}{l}\text { Unstandardized } \\
\text { Coefficients }\end{array}$} & \multirow{2}{*}{$\begin{array}{c}\text { Standardized } \\
\text { Coefficients } \\
\text { Beta }\end{array}$} & \multirow[t]{2}{*}{$\mathbf{T}$} & \multirow[t]{2}{*}{ Sig. } \\
\hline & B & Std. Error & & & \\
\hline $\begin{array}{ll}1 & \text { (Constant) }\end{array}$ & $-1,287$ & 1,418 & & $-0,908$ & 0,369 \\
\hline Struktur Audit $\left(\mathrm{X}_{1}\right)$ & 0,423 & 0,103 & 0,343 & 4,124 & 0,000 \\
\hline $\begin{array}{l}\text { KomitmenOrganisasi } \\
\left(\mathrm{X}_{2}\right)\end{array}$ & 0,193 & 0,042 & 0,386 & 4,558 & 0,000 \\
\hline $\begin{array}{l}\text { Gaya Kepemimpinan } \\
\text { Transformasional }\left(\mathrm{X}_{3}\right)\end{array}$ & 0,227 & 0,059 & 0,335 & 3,880 & 0,000 \\
\hline F hitung & 56,607 & & & & \\
\hline Signifikansi F & 0,000 & & & & \\
\hline R Square & 0,776 & & & & \\
\hline Adjusted R Square & 0,762 & & & & \\
\hline
\end{tabular}

Sumber: Data diolah, 2017

Berdasarkan hasil analisis regresi pada tabel 2. diperoleh model regresi sebagai berikut:

$$
\hat{Y}=-1,287+0,423 X_{1}+0,193 X_{2}+0,227 X_{3}+\varepsilon
$$

Model regresi tersebut menunjukkan arah hubungan masing-masing variabel bebas terhadap variabel terikatnya. Koefisien regresi variabel struktur audit memiliki nilai $\beta=0,423$. Tanda positif menunjukkan bahwa struktur audit memiliki arah hubungan yang searah dengan kinerja auditor. Apabila struktur audit meningkat maka kinerja auditor akan meningkat.

Koefisien regresi variabel komitmen organisasi memiliki nilai $\beta=0,193$. Tanda positif menunjukkan bahwa komitmen organisasi memiliki arah hubungan yang searah dengan kinerja auditor. Apabila komitmen organisasi meningkat maka kinerja auditor akan meningkat.

Koefisien regresi variabel gaya kepemimpinan transformasional memiliki nilai $\beta=0,227$. Tanda positif menunjukkan bahwa gaya kepemimpinan 
transformasional memiliki arah hubungan yang searah dengan kinerja auditor. Apabila gaya kepemimpinan transformasional meningkat maka kinerja auditor akan meningkat.

Berdasarkan hasil analisis data diperoleh nilai Adjusted R-Square sebesar 0,762. Hal ini berarti bahwa sebesar 0,762 atau $76,2 \%$ variasi kinerja auditor mampu dijelaskan oleh variabel struktur audit, komitmen organisasi, dan gaya kepemimpinan transformasional. Sisanya sebesar $23,8 \%$ dipengaruhi oleh variabel lain yang tidak masuk dalam model.

Uji F digunakan untuk melihat kelayakan model penelitian. Uji statistik F pada dasarnya bertujuan untuk melihat apakah semua variabel independen atau bebas yang dimaksud dalam model mempunyai pengaruh secara serempak terhadap variabel dependen atau terikat. Berdasarkan model yang telah dianalisis, diketahui $\mathrm{F}_{\text {hitung }}$ sebesar 56,607, signifikansi (p-value) sebesar 0,000.

Berdasarkan nilai toleransi yang diberikan yaitu $\alpha=5 \%$ dengan nilai signifikansi $0,000<\alpha(0,05)$, maka hubungan antara struktur audit, komitmen organisasi, dan gaya kepemimpinan transformasional adalah berpengaruh positif signifikan terhadap kinerja auditor pada KAP di Bali dan model regresi yang digunakan dianggap layak uji.

Uji hipotesis menggunakan uji t (t-test) yang dilakukan untuk menguji hipotesis yang menyatakan bahwa struktur audit, komitmen organisasi, dan gaya kepemimpinan transformasional berpengaruh positif terhadap kinerja auditor pada KAP di bali. 
Berdasarkan Tabel 2. diperoleh tingkat signifikansi 0,000<0,005, maka $\mathrm{H}_{0}$ ditolak. Hal ini berarti terdapat pengaruh positif yang signifikan secara parsial struktur audit terhadap kinerja auditor pada KAP di Bali. Berdasarkan Tabel 2. diperoleh tingkat signifikansi $0,000<0,005$, maka $\mathrm{H}_{0}$ ditolak. Hal ini berarti terdapat pengaruh positif yang signifikan secara parsial komitmen organisasi terhadap kinerja auditor pada KAP di Bali. Berdasarkan Tabel 2. diperoleh tingkat signifikansi $0,000<0,005$, maka $\mathrm{H}_{0}$ ditolak. Hal ini berarti terdapat pengaruh positif yang signifikan secara parsial gaya kepemimpinan transformasional terhadap kinerja auditor pada KAP di Bali.

\section{SIMPULAN}

Berdasarkan hasil pembahasan analisis data melalui pembuktian terhadap hipotesis dari permasalahan yang diangkat analisis pengaruh struktur audit, komitmen organisasi, dan gaya kepemimpinan transformasional pada kinerja auditor dapat disimpulkan bahwaStruktur Audit berpengaruh positif signifikan terhadap kinerja auditor di Kantor Akuntan Publik (KAP) di Bali. Hal ini berarti bahwa semakin baik struktur audit maka semakin baik pula kinerja auditornya.

Komitmen Organisasi berpengaruh positif signifikan terhadap kinerja auditor di Kantor Akuntan Publik (KAP) di Bali. Hal ini berarti bahwa semakin baik komitmen organisasi maka semakin baik pula kinerja auditornya. Gaya Kepemimpinan Transformasional berpengaruh positif signifikan terhadap kinerja auditor di Kantor Akuntan Publik (KAP) di Bali. Hal ini berarti bahwa semakin baik gaya kempimpinan transformasional maka semakin baik kinerja auditornya. 
Berdasarkan hasil penelitian dan simpulan di atas, maka saran yang dapat disampaikan hasil penelitian ini adalah memperhatikan dan melaksanakan dengan sungguh-sungguh indikator nomor satu dari variabel struktur audit yakni prosedur atau aturan pelaksanaan audit yang saya gunakan audit yang sangat rinci karena indikator ini nilainya terendah dibandingkan indikator lainnya. Hal tersebut berarti prosedur atau aturan dalam melaksanakan audit harus jelas dan lebih rinci, sehingga dapat meningkatkan kinerja auditor dalam melaksanakan audit menjadi semakin baik.

Merasa menjadi bagian dari organisasi tempat saya bekerja yang merupakan indikator keempat dari variabel komitmen organisasi kepada auditor karena dalam organisasi harus meningkatkan komunikasi, dan rasa memiliki terhadap organisasi agar seorang auditor dapat merasa menjadi bagian dari organisasi tersebut sehingga dapat meningkatkan kinerja auditor menjadi lebih baik.

Seorang pemimpin harus selalu menekankan pekerjaan dengan memfokuskan pada tujuan dan hasil karena sikap ini diperlukan dalam proses pengauditan agar tujuan dan hasil dari organisasi tersebut dapat tercapai sehingga menimbulkan kinerja auditor yang semakin baik. Pernyataan tersebut merupakan indikator kesembilan dari variabel gaya kepemimpinan transformasional sehingga memberikan opini yang merupakan keharusan seorang auditor akan bisa terpenuhi apa bila sikap-sikap ini diterapkan oleh supervisi audit.

Besarnya kompensasi yang saya terima akan mempengaruhi saya dalam melaporkan kesalahan klien merupakan indikator pertama dari variabel kinerja 
auditor. Sikap indikator ini diperlukan karena seorang auditor sebagai pekerja di klien sangat dibutuhkan. Hal tersebut berarti ada suatu regulasi yang mengatur standarisasi kompensasi sehingga tidak ada lagi masalah menyebabkan menurunnya kinerja pelaporan kesalahan klien,sehingga dapat disimpulkan bahwa kinerja auditor sudah tergolong baik.

Bagi peneiti selanjutnyadiharapkan bisa melakukan uji moderasi dari gaya kepemimpinan transformasional dan komitmen organisasi terhadap struktur audit. Penelitian selanjutnya dapat mempertimbangkan penggunaan variabel independen lain yang secara teoritis mungkin dapat mempengaruhi kinerja auditor yaitu motivasi, supervisi, pengalaman kerja, tingkat pendidikan, indepedensi, dan budaya organisasi. Objek dalam penelitian ini hanya terbatas untuk KAP di Bali, sehingga penelitian selanjutnya diharapkan dapat melakukan penelitian dengan objek yang berbeda seperti inspektorat, BPKP, dan organisasi-organisasi lainnya yang berhubungan dengan auditor.

\section{REFERENSI}

Adeyemi, Semiu Babatunde and Fagbemi, Temitope Olamide. 2010. Audit Quality, Corporate Governance and Firm Characteristics in Nigeria. International Journal of Business and Manajement, 5(5): pp: 1-11

Arifah, Nurul. 2012. Pengaruh Independensi Auditor, Komitmen Organisasi, dan Gaya Kepemimpinan Terhadap Kinerja Auditor. Skripsi. Universitas Hasanudin, Makasar.

Bamber , E.M., et al. 1989. Audit Structureand Its Relation to Role Conflict and Role Ambiguity: An Empirical Investigation. The Accounting Review.

Cavazott, Flavia, Valter Moreno, and Mateus Hickmann, 2011. Effects of Leader Intelligence, Personality and Emotional Intelligence on Transformational leadership and Managerial Performance. The Leadership Quarterly, 23 (2012) pp: 443-455. 
Ciarrochi, J., Deance, F.P. Anderson , S. 2002. Emotional Intelligence Moderates the Relationship between Stress and Metal Health. Personality and Individual Differences. Personality and Individual Differences 32: pp: 197-209

Danielle E. Warren dan Miguel Alzola. (2008). Ensuring Independent Auditors: Increasing the Saliency of the Profesional Indentity. Journal Group Decis Negot (2009) 18: pp:41-56.

Fanani, Hanif, dan Subroto 2008, "Pengaruh Struktur Audit, Konflik Peran, dan Ketidakjelasan Peran terhadap Kinerja Auditor, “ Jurnal Akuntansi dan Keuangan Indonesia, Vol. 5, No. 2, Desember. 139-155.

Fanani, Zaenal., Hanif, Rheny dan Bambang Subroto. Pengaruh Struktur Audit, Konflik Peran, dan Ketidakjelasan Peran Terhadap Kinerja Auditor, The First Accounting Conference, Faculty of Economics Universitas Indonesia. Depok, 2007.

Hanif, Rheny Afriana. 2013. Pengaruh Struktur Audit, Konflik Peran, dan Ketidakjelasan Peran Terhadap Kinerja Auditor. Jurnal Ekonomi. September, 21(3):h:1-15

Heny Arianti , 2015. Faktor-fakktor yang Mempengaruhi Kinerja Auditor. (Studi Empiris Pada KAP di Surakarta Dan Yogyakarta). Skripsi. Universitas Muhammadiyah Surakarta.

Indrayanto, A., John, B., Kandy, B., dan Noermijati. 2013. "A case study of transformational leadership and para - police performance in indonesia. "Policing : An International Journal Of Police Strategies And Management. Vol. 37. No. 2. pp 373 - 388. Emerald Insight.

Jamilah, Siti, Zaenal Fanani, dan Grahita Chandrarin, 2007. Pengaruh Gender, Tekanan Ketaatan, dan Kompleksitas Tugas Terhadap Audit Judgment. Simposium Nasional Akuntansi Unhas Makassar. h: 1-30

Kallbers, Lawrens P., \& Forgarty, Timothy J. 1995. Pofesionalism Its Consequences: A Study of Internal Auditors. Auditing: A Journal of Practice, 14(1): pp:64-86.

Luthans, Fred, 2006. Perilaku Organisasi Edisi Sepuluh, Yogyakarta: Penerbit Andi.

Mangkunegara, Anwar Prabu. 2005. Evaluasi Kinerja SDM. Bandung: Refika Aditama.

Mahsun, Mohamad, Firma Sulistyowati, Heribertus Andre Purwanugraha, 2007. Akuntansi Sektor Publik. Yogyakarta: BPFE Yogyakarta. 
Marganingsih, dan Martini. "Analisis Variabel Atesenden Perilaku Auditor Internal dan Konsekuensinya terhadap Kinerja : Studi Empiris pada auditor di lingkungan aparat Pengawasan Intern Pemerintah-Lembaga Pemerintah NonDepartemen. http://www.scribd.com/doc/27749062/Analisa-Perilaku-AuditorTerhadap-Kinerja.

Mulyadi, 2009, Auditing, Edisi ke-6, Buku I, Salemba Empat, Jakarta.

Mulyadi dan Kanaka Puradiredja. 1998. Auditing Pendekatan Terpadu. Jakarta: Salemba Empat.

Rahmawati. 2011. Pengaruh Role Stress terhadap Kinerja Auditor dengan Emotional Quotient sebagai Variabel Moderating. Skripsi. Universitas Islam Negeri Syarif Hidayatullah.

Satwika, Adhi Nugraha dan Ramantha, I Wayan. 2015. Pengaruh Profesionalisme, Etika Profesi, dan pelatihan Auditor Terhadap Kinerja Auditor pada Kantor Akuntan Publik di Bali. E-Jurnal Akuntansi Universitas Udayana, 13(3): h:916-943.

Stuart, Irish dan Doughlas F,Prawitt. The Influence of Audit Structure on Auditors Performance in High and Low Complexity Task Setting. Journal of Behavior Research In Accounting, Volume 11, 2004.

Suseno, Novie Susanti. 2013. Literature Riview The Effect Of Indepedence, Size Of Public Accountant Office Toward Audit Quality And Its Impact On Public Accountant Reputation. Journal of Applied Sciences Researches. 9(1): p:62-66.

Sugiyono. 2014. Metode Penelitian Bisnis. Bandung: Alfabeta

Sina, Muhamad Ibnu. 2013. Analisis Pengaruh Gaya Kepemimpinan Transformasional terhadap Kinerja Karyawan Dengan Komitmen Organisasi sebagai Variabel Intervening. Skripsi. Fakultas Ekonomi dan Bisnis Universitas Diponegoro Semarang.

Tintamin, Lila, Ari Pradhanawati, Hari susanto, 2012. Pengrauh Budaya Organisasi dan Gaya Kepemimpinan Transformasional terhadap Kinerja Karyawan Melalui Disiplin Kerja pada Karyawan Harian SKT Megawon II PT. Djarum Kudus. Diponegoro Journal of Social and Politic. h: 1-8.

Triandis, Harry. C. 1971. Attitude and Attitude Change. Toronto: John Willey \& Sons.

Timothy, Obiwuru C., Okwu, A. T., Akpa, V. O., \& Nwankwere, I. A. 2011. Effects of leadership style on organizational performance: A survey of selected small scale enterprises in Ikosi-Ketu council development area 
ISSN: 2302-8556

E-Jurnal Akuntansi Universitas Udayana

Vol.24.3.September (2018): 1658-1686

of Lagos State, Nigeria. Australian Journal of Business and Management Research, 1(7) pp: 100- 111.

Wibowo (2009), Hian Ayu Oceani, 2009, "Pengaruh Indepedensi Auditor, Komitmen Organisasi, Gaya kepemimpinan, Dan Pemahaman Good Governance terhadap kinerja auditor (Studi Empiris Pada Kantor Akuntan Publik Di Daerah Istimewa Yogyakarta). "Skripsi, Fakultas Ekonomi Universitas Islam Indonesia. 